\title{
Inhibitor of pro-apoptotic PERK-dependent signalling pathway as a novel treatment strategy in Alzheimer's disease treatment
}

\author{
Inhibitor proapoptotycznego szlaku sygnałowego zależnego od kinazy PERK \\ jako nowa strategia terapeutyczna w leczeniu choroby Alzheimera
}

Wioletta Rozpędek ${ }^{1}$, Justyna Basak ${ }^{1}$, Igor Sokołowski ${ }^{1}$, Radosław Wojtczak ${ }^{1}$, Dariusz Pytel ${ }^{2}$, Alan J. Diehl², Ireneusz Majsterek ${ }^{1}$

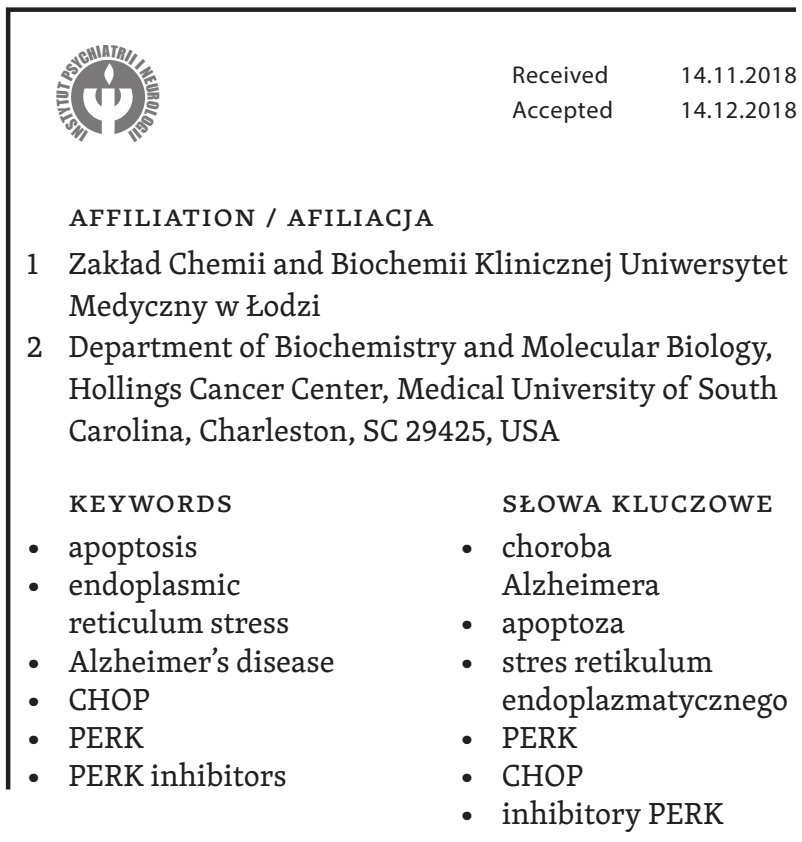

CORRESPONDENCE ADDRESS / ADRES DO KORESPONDENCJI Ireneusz Majsterek

Zakład Chemii and Biochemii Klinicznej Uniwersytet Medyczny w Łodzi

ul. Hallera 1, 90-647 Łódź, Poland

email: ireneusz.majsterek@umed.lodz.pl

\begin{abstract}
Objectives. The newest data reported that Alzheimer's disease $(\mathrm{AD})$ pathogenesis and progression are correlated with excessive activation of Endoplasmic Reticulum (ER) stress conditions and, as a result, pro-apoptotic branch of the protein kinase RNA-like ER kinase (PERK)-dependent Unfolded Protein Response (UPR) signalling pathway, in which the major apoptotic marker constitutes C/EBP homologous protein (CHOP). The aims of the study were the evaluation of LDN-0060609 in terms of its inhibitory activity towards pro-apoptotic branch of the PERK-dependent UPR signalling pathway as well as evaluation of LDN-0060609 cytotoxicity.

Material and methods. Research was conducted on mouse neurons CATH.a. Cells were incubated with LDN0060609 at the concentration range and with thapsigargin as an activator of ER stress. Evaluation of CHOP protein level was performed by Western Blot technique; apoptosis analysis - by flow cytometry; whereas evaluation of LDN-0060609 cytotoxicity - by XTT assay.

Results. The results of the study showed that inhibitor LDN-0060609 at $25 \mu \mathrm{M}$ concentration evokes $80 \%$ decrease in the CHOP protein level as compared to untreated control cells. Additionally, at 25 $\mu \mathrm{M}$, LDN-0060609 effectively inhibits apoptosis in cells with activated ER stress. Only $5.6 \%$ less viable cells were shown as compared to control cells incubated with $0.01 \%$ DMSO.
\end{abstract}


LDN-0060609 did not evoke a cytotoxic effect at any used concentrations and incubation times.

Conclusions. The results of our own research showed that LDN-0060609 inhibitor effectively inhibits apoptosis-mediated neuronal cell death and does not evoke a cytotoxic effect. Thus, low-molecular inhibitors of pro-apoptotic branch of PERK-dependent UPR signalling pathway may constitute an innovative therapeutic strategy for $\mathrm{AD}$ treatment.

\section{STRESZCZENIE}

Cel pracy. Najnowsze doniesienia naukowe wskazują, iż patogeneza oraz progresja choroby Alzheimera (AD) są skorelowane z nadmierną aktywacją stresu retikulum endoplazmatycznego (Endoplasmic Reticulum, ER), a w efekcie proapoptotycznej drogi szlaku adaptacyjnej odpowiedzi na stres (Unfolded Protein Response, UPR), zależnego od kinazy PERK (protein kinase RNA-like ER kinase), w którym główny marker apoptotyczny stanowi białko CHOP (C/EBP homologous protein). W związku z powyższym celem badania była analiza związku LDN-0060609 pod względem jego aktywności inhibicyjnej proapoptotycznego szlaku sygnałowego UPR zależnego od kinazy PERK oraz ocena cytotoksyczności inhibitora LDN-0060609.

Materiał i metody. Badanie przeprowadzono na linii komórkowej neuronów mysich CATH.a. Komórki

\section{Objective}

Alzheimer's disease (AD) is one of the most common neurodegenerative diseases, the most significant features of which are a decrease in the brain neural tissue mass and progressive disorders of cognitive functions (Hashimoto and Saido 2018, Kinney et al. 2018, Prasanthi et al. 2011). AD is the main cause of dementia and dullness in the elderly. It is currently estimated that the number of cases of $A D$ in the world in 2050 could reach 130 million (Hashimoto and Saido 2018, Sun et al. 2018). Therefore, its constantly increasing incidence rate implies the need for further research into aetiology and more effective therapies for treating AD (Kinney et al. 2018). The pathogenesis of $A D$ is primarily related to the deposition of neurotoxic deposits of $\beta$ amyloid $\beta$ of 42 amino acids $\left(A \beta_{42}\right)$, mainly in the hippocampus and brain cortex (Salminen et al. 2009, Endres and Reinhardt 2013, Sun et al. 2018). Recent scientific reports underline that activation of endoplasmic reticulum (ER) as a result of accumulation of misfolded proteins in the ER lumen plays an important role in the development and progression of AD. This leads to significant disturbances in cell signalling, dysfunction in the functioning of neurons and then their apoptosis, which is a key factor in the progress inkubowano z testowanym inhibitorem LDN-0060609 w szeregu stężeń na odpowiedniej pożywce hodowlanej z tapsygarginą jako aktywatorem stresu ER. Oceny poziomu białka CHOP dokonano przy użyciu techniki Western Blot. Analiza apoptozy została wykonana za pomocą cytometrii przepływowej. Ocenę cytotoksyczności związku LDN-0060609 przeprowadzono za pomocą testu XTT.

Wyniki. Przeprowadzone badania wykazały, iż inhibitor LDN-0060609 w stężeniu $25 \mu \mathrm{M}$ wywołuje $80 \%$ spadek poziomu białka CHOP w porównaniu z komórkami kontrolnymi nietraktowanymi żadnym związkiem. Ponadto w stężeniu $25 \mu \mathrm{M}$ związek LDN-0060609 skutecznie hamuje apoptozę w komórkach z aktywowanym stresem ER. Wykazano jedynie o 5,6\% mniej żywych komórek w porównaniu z kontrolą, którą stanowiły komórki inkubowane z 0,01\% DMSO. Inhibitor LDN-0060609 nie wywołał efektu cytotoksycznego w żadnym z zastosowanych stężeń oraz czasów inkubacji.

Wnioski. Wyniki badań własnych wykazały, iż inhibitor LDN-0060609 skutecznie hamuje śmierć komórek neuronalnych na drodze apoptozy oraz nie wywołuje efektu cytotoksycznego. Niskocząsteczkowe inhibitory proapoptotycznego szlaku UPR zależnego od kinazy PERK mogą stanowić zatem innowacyjną strategię terapeutyczną w leczeniu AD.

of the disease (Hashimoto and Saido 2018, Lindholm et al. 2006).

There is abundance of scientific evidence that Unfolded Protein Response (UPR) disorders, in which PERK kinase protein (RNA-like ER kinase) plays a key role, are closely related to the pathogenesis and progression of numerous human diseases, including neurodegenerative diseases (Wang and Kaufman 2012). Apart from its pro-adaptive character conditioning the behaviour of intracellular homeostasis, the UPR pathway is of a twofold nature. In conditions of intensified and prolonged stress, ER may show the pro-apoptotic character (Hashimoto and Saido 2018, Salminen et al. 2009). Next, the PERK is autophosphorylated and then its main substrate - translation initiation factor 2 (eIF2) in a subunit - is phosphorylated, which results in inhibition of translation of the majority of proteins in the cell (Endres and Reinhardt 2013). Certain transcripts with sequences binding the phosphorylated eIF2 factor are an exception. This increases the level of translation of preferential proteins only, which include $\beta$ secretase (BACE1), an enzyme cleaving the precursor form of $A \beta$ (amyloid precursor protein, APP). As a result, more of the abnormal form of $A \beta$ is deposited in the cerebral tissue, thus worsening the stress of ER (Salminen et al. 
2009). At the same time, the ATF4 protein (Activating Transcription Factor 4), stimulating transcription of both chaperones and proteins inducing the process of autophagy and apoptosis, is activated under the influence of phosphorylated form of eIF2 factor (Hashimoto and Saido 2018, Endres and Reinhardt 2013). The most important pro-apoptotic proteins associated with ER stress include CHOP (C/EBP homologous protein). In homeostatic conditions, the expression of this protein is at a very low level; however, under the influence of pro-apoptotic pathway induced by PERK in conditions of ER stress, its significant increase takes place (Nishitoh 2012). CHOP is a transcription factor for genes that can determine cell survival or death (Li et al. 2015). One of the key mechanisms by which CHOP controls switching the cell to the apoptosis pathway is to inhibit the synthesis of anti-apoptotic Bcl-2 proteins (B-cell lymphoma 2) (Tabas and Ron 2011, Li et al. 2015). CHOP may also increase the level of pro-apoptotic transcriptions of Bcl-2 family members, such as BAX protein, as well as affect the expression of GADD34 (DNA damage-inducible protein) responsible for eIF2 dephosphorylation, thus causing the restoration of inhibited protein synthesis and intensification of ER stress (Rozpedek et al. 2016, Li et al. 2015). $\mathrm{CHOP}$ is also responsible for inducing oxidative stress in the ER lumen by including transcription of endoplasmic reticulum oxidase $1 a$ (ERO1a), which induces a strongly oxidised environment inside ER and in cytoplasm. The consequence of increased production of reactive oxygen species (ROS) caused by activation of pro-apoptotic PERK-dependent UPR pathway may be the apoptotic cell death and a significant increase in $\beta$ secretase expression, which additionally enhances $\mathrm{A} \beta$ oligomerisation (Tabas and Ron 2011, Prasanthi et al. 2011). It was proved that inhibition of CHOP expression significantly affects the level of proteins from Bcl-2 family and reduces the incidence of other pathological processes characteristic for $A D$, such as increased production of $A \beta$, increased oxidative stress or iron homeostasis dysfunctions, which indicates that lowering the level of CHOP protein may be of key importance for AD treatment (Prasanthi et al. 2011).

Therefore, the objective of the study was to analyse a small-molecule compound LDN-0060609 in terms of its activity of inhibiting pro-apoptotic PERK-dependent UPR pathway and to evaluate the cytotoxicity of LDN0060609 inhibitor.

\section{Method}

The LDN-0060609 inhibitor was selected in cooperation with Professor J. Alan Diehl's laboratory (Medical University of South Carolina, Hollings Cancer Center, Charleston, USA) on the basis of docking a computer database of small-molecule compounds contained in the Laboratory for Drug Discovery in Neurodegeneration (LDDN) library, TRF-FRET test, radiometric kinase test, and then on the basis of in vitro model analyses on cell lines.

The CATH.a. mouse neuron cell line (ATCC ${ }^{\circledR}$ CRL$\left.11179^{\mathrm{TM}}\right)$, on which this study was performed, had been obtained from the American Type Culture Collection (ATCC; Manassas, VA, USA). CATH.a cell line was cultured in accordance with the manufacturer's guidelines on RPMI-1640 medium supplemented with $8 \%$ horse serum (ATCC ${ }^{\circledR} 30-2040^{\mathrm{TM}}$ ), $4 \%$ foetal bovine serum (ATCC $30-2020)$ as well as $100 \mathrm{U} / \mathrm{mL}$ penicillin and $100 \mu \mathrm{g} / \mathrm{mL}$ streptomycin (Gibco-BRL, 15140-122). The cell culture was carried out at $37^{\circ} \mathrm{C}, 5 \% \mathrm{CO}_{2}$ and $95 \%$ humidity.

CATH.a cells were pre-incubated for 1 hour with the tested LDN-006060609 inhibitor in a series of concentrations of $6 \mu \mathrm{M}-50 \mu \mathrm{M}$. Then, the cells were treated with thapsigargin (Th) as an ER stress activator at the concentration of $500 \mathrm{nM}$ and incubated simultaneously with Th and LDN-0060609 for 2 hours. Positive control were cells treated exclusively with $\mathrm{Th}$ at the concentration of $500 \mathrm{nM}$ for 2 hours, while negative control were cells not treated with any compound. Additional control were cells subjected to 1-hour pre-incubation with commercially available inhibitor GSK2606414 (GlaxoSmithKline) at the concentration of $1 \mu \mathrm{M}$, then treated with Th at the concentration of $500 \mathrm{nM}$ and incubated simultaneously with Th and GSK2606414 for 2 hours.

The analysis of the CHOP protein level was performed using the Western Blot technique. After prior incubation of CATH.a cells with the tested LDN-0060609 compound and $\mathrm{Th}$, they were collected and subjected to lysis with EBC buffer ( $50 \mathrm{mM}$ Tris- $\mathrm{HCl}, 120 \mathrm{mM} \mathrm{NaCl}, 0.5 \%$ NP40) with protease and phosphatase inhibitor cocktail (Thermo Fisher Scientific Inc., USA). The homogenate was frozen and stored at $-80^{\circ} \mathrm{C}$ until the determinations were carried out. Then, the total amount of protein in the analysed tests was measured using the Bradford method. The calibration curve was performed using a number of dilutions of bovine serum albumin. Tests diluted with ECB buffer and filled up to the ratio of 1:1with a denaturing buffer $2 \times$ Laemmli (Bio-Rad Laboratories, Hercules, CA) containing 2-mercaptoethanol (Sigma-Aldrich Corp., St. Louis, MO, USA) were denatured at $95^{\circ} \mathrm{C}$. Samples containing $90 \mu \mathrm{g}$ of total protein were subjected to electrophoretic separation in $10 \%$ polyacrylamide gel under denaturing conditions. Then, the proteins were transferred from gel to PVDF membrane (Immobion-P, Merck Milipore, Billerica, MA, USA) during wet electro-transfer. The membrane was then blocked for 1 hour at room temperature in 5\% non-fat cow milk solution (Bio-Rad Laboratories, Hercules, CA) in buffer 1 X TBS/0.05\% Tween 20 to prevent non-specific binding of proteins on the membrane. The membranes were incubated for 16 hours at $4^{\circ} \mathrm{C}$ with specific primary antibodies, i.e. CHOP, $\beta$-actin (1:1000; Cell Signaling Technology, Inc., Danvers, MA, USA). Then, after rinsing the excess primary antibodies with $1 \mathrm{X}$ TBST buffer, the 
membranes were incubated for 1 hour at room temperature with HRP-conjugated secondary antibodies (1:5000; Cell Signaling Technologies). Detection of immune complexes was carried out using an ECL chemiluminescent kit (Bio-Rad Laboratories, Hercules, CA). Densitometry of the striae was performed using Gene Tools software (Syngene, Cambridge, UK). The amount of protein was normalised in relation to the signal obtained for $\beta$-actin as a reference protein.

Apoptosis analysis was performed with double staining with annexin $\mathrm{V}(\mathrm{Ann}-\mathrm{V})$ and propidine iodide (PI) using flow cytometry. Cells on $10 \mathrm{~cm}$ culture plates were subjected to 1-hour pre-incubation with LDN0060609 inhibitor at the concentrations of $6 \mu \mathrm{M}$ and $25 \mu \mathrm{M}$; subsequently, they were treated with Th at the concentration of $500 \mathrm{nM}$ and incubated simultaneously with Th and LDN-0060609 for 24 hours. Control cells were treated with $10 \mathrm{ml}$ of medium containing $1 \mu \mathrm{l}$ of DMSO and incubated for 24 hours. The cells were then collected and washed in $1 \mathrm{X}$ Dulbecco phosphate buffered saline (DPBS, Corning, NY USA, 21-031). Cells at the concentration of $1 \times 10^{6} / \mathrm{ml}$ were suspended in $1 \mathrm{X}$ Binding Buffer and $100 \mu \mathrm{l}$ of cell suspension $\left(1 \times 10^{5}\right.$ cells $)$ was transferred to $5 \mathrm{ml}$ Eppendorf tubes. Each of the analysed tests was stained with $5 \mu \mathrm{l} \mathrm{Ann-V}$ and $5 \mu \mathrm{l}$ PI, vortexed and incubated in the dark at room temperature for $15 \mathrm{~min}$. Each test was then diluted with $400 \mu \mathrm{l}$ of $1 \mathrm{X}$ Binding Buffer and analysed by flow cytometry using a Beckman Coulter CytoFLEX cytometer. The obtained data were analysed using the Kaluza analysis 1.5A software (Beckman Coulter).

The analysis of cytotoxicity of the LDN-0060609 inhibitor was performed using the colorimetric XTT test. CATH.a cells were seeded on a 96 -well culture plate at the concentration of $8 \times 10^{6} /$ well of culture plate in accordance with the manufacturer's recommendations in a suitable culture medium. After 24 hours of incubation, the medium was removed and the cells were treated with $100 \mu \mathrm{l}$ of medium containing the studied LDN-0060609 inhibitor at the concentrations of $6 \mu \mathrm{M}, 12 \mu \mathrm{M}, 25 \mu \mathrm{M}, 50$ $\mu \mathrm{M}$ and $0.5 \mathrm{mM}$. The cells treated with $100 \mu \mathrm{l}$ of culture medium containing $1 \mu \mathrm{l}$ DMSO (Sigma-Aldrich Corp., St. Louis, MO, USA; 67-68-5), a solvent for the tested inhibitor, were the positive control, while the cells treated only with $100 \mu 1$ 99.9\% DMSO were the negative control. Each of the analysed tests was repeated three times. The cells were incubated for 16, 24 and 48 hours. After 16, 24, 48 hours respectively, $25 \mu \mathrm{l}$ of XTT/PMS mixture (Thermo Fisher Scientific Inc., USA; X-6493; AC130160010) prepared in accordance with the manufacturer's recommendations were added to each test sample. The cells were incubated for 2 hours at $37^{\circ} \mathrm{C}, 5 \% \mathrm{CO}_{2}$ and $95 \%$ humidity. Absorbance was measured at $450 \mathrm{~nm}$ wavelength using Synergy HT (BioTek) plate reader.

The statistical analysis was carried out by means of a Student's t-test using STATISTICA 10 (StatSoft) software.

\section{Results}

The analysis of pro-apoptotic CHOP protein level in CATH.a cells showed its highest level in the cells treated exclusively with $T h$ as the ER $\left(K_{\mathrm{T}}\right)$ stress activator. After 1 hour of cell pre-incubation with commercially available GSK2606414 inhibitor $(1 \mu \mathrm{M})$, followed by 2 hours of simultaneous incubation with GSK2606414 $(1 \mu \mathrm{M})$ and Th, a 79\% decrease in CHOP protein level was observed. As a result of 1 hour pre-incubation of cells with the tested LDN-0060609 inhibitor at $25 \mu \mathrm{M}$ concentration, the greatest decrease $(80 \%)$ in the level of CHOP protein was observed as compared to the cells not treated with any of the compounds (K) (Figure 1).
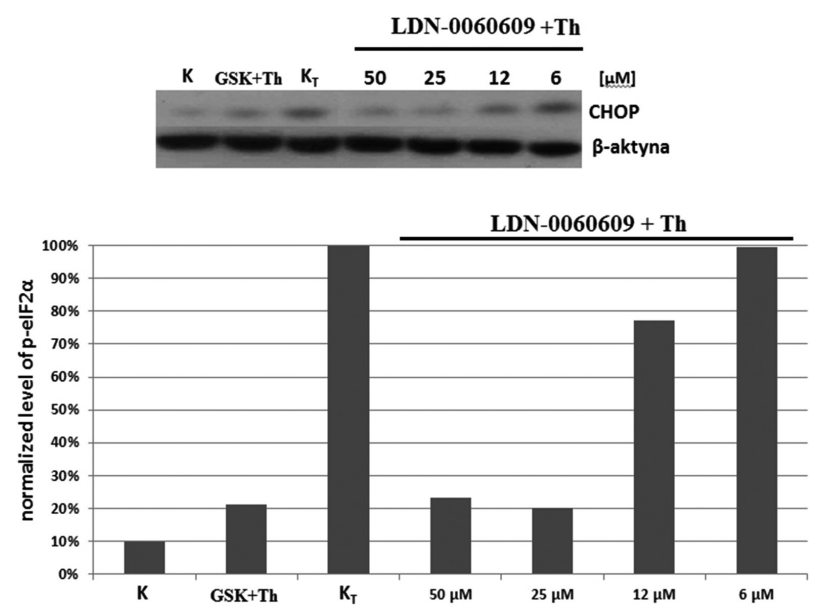

Figure 1 Analysis of the LDN-0060609 compound inhibitory activity via the evaluation of the level of the pro-apoptotic CHOP protein in CATH.a cell line LDN-0060609 - tested inhibitor; Th - thapsigargin; CHOP -C/EBP homologous protein; $\mathrm{K}$ - untreated cells; GSK+Th - cells treated with inhibitor GSK2606414 and thapsigargin; KT - cells treated with thapsigargin

The analysis of the influence of LDN-0060609 inhibitor on the process of apoptosis inhibition in CATH.a. cells with activated ER stress revealed $81.6 \%$ of live cells, $16.6 \%$ of cells in early and late apoptosis and $2 \%$ of cells in necrosis as a result of their 24 -h incubation with the tested LDN-0060609 inhibitor at the concentration of 25 $\mu \mathrm{M}$. The 24-hour incubation of CATH.a cells with activated ER stress, with LDN-0060609 inhibitor at a lower concentration $(6 \mu \mathrm{M})$, showed $54.9 \%$ of live cells, $27.3 \%$ of cells in early and late apoptosis and $18.7 \%$ of cells in necrosis. Therefore, the 24-hour incubation of CATH.a cells with activated stress ER with LDN-0060609 inhibitor at $25 \mu \mathrm{M}$ concentration showed only $5.6 \%$ less live cells as compared with the control, which were CATH.a cells incubated for 24 hours with $0.01 \%$ DMSO, a solvent for the tested inhibitor. In CATH.a cells with activated ER stress treated with $25 \mu \mathrm{M}$ of LDN-006060609, only 5.1\% more cells were observed in early and late apoptosis as compared with the control used (Figure 2). 
DMSO

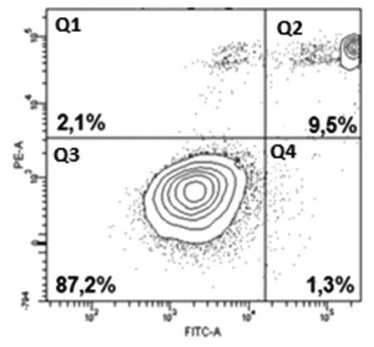

$6 \mu \mathrm{M} \mathrm{LDN}-0060609+\mathrm{Th}$

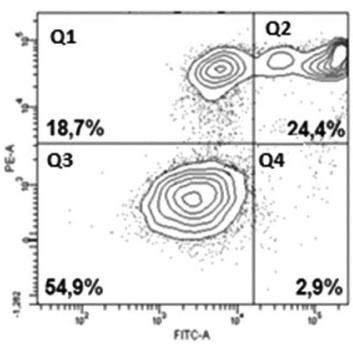

$25 \mu \mathrm{M}$ LDN-0060609+Th

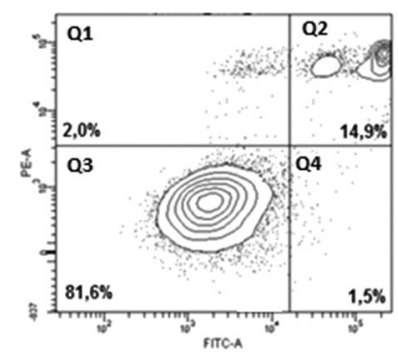

Figure 2 Analysis of the effect of inhibitor LDN-0060609 on apoptotic inhibition process in CATH.a. cell line DMSO - cells treated with 0,01\% dimethyl sulfoxide; LDN-0060609 - tested inhibitor; Th - thapsigragin; Q1 - necrotic cells; Q2 - late-apoptotic cells; Q3 - live cells; Q4 - early-apoptotic cells

The analysis of LDN-006060609 inhibitor cytotoxicity, performed with XTT test, did not show its significant effect on CATH.a cell viability at any of the applied concentrations and incubation times. The level of statistical significance was not achieved $(p<0.05)$ (Figure 3$)$.

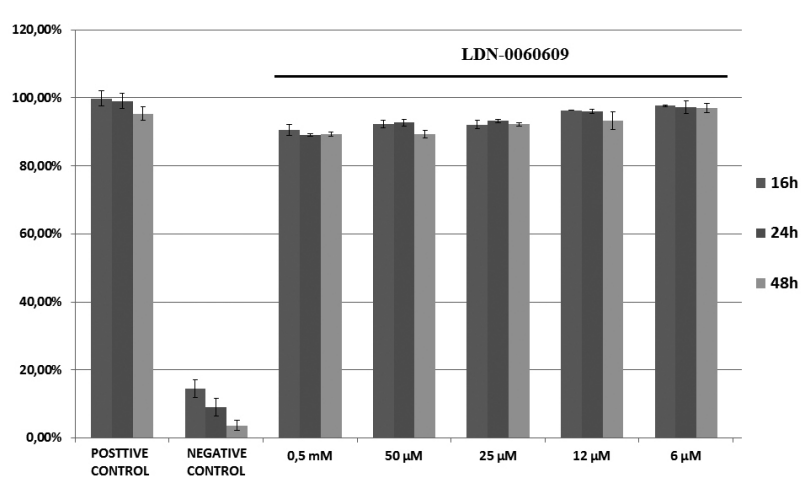

Figure 3 Evaluation of cytotoxicity of inhibitor LDN-0060609 on CATH.a cell line LDN-0060609 - tested inhibitor; positive control - cells treated with $0,01 \%$ dimethyl sulfoxide; negative control - cells treated with $99,9 \%$ dimethyl sulfoxide

\section{Overview}

AD, which belongs to the group of neurodegenerative diseases, is characterised by cognitive function dysfunctions, mainly memory, as well as emotional and behavioural disorders (Elferink et al. 2015). AD is the most common cause of dementia as it accounts for as much as 75\% of all cases of dementia. Epidemiological studies indicate that, due to the progressive ageing of the population, the incidence of $\mathrm{AD}$ in patients between the ages of 65 and 85 in particular continues to increase. After the age of 65 , the incidence of $\mathrm{AD}$ doubles every 5 years, so nowadays $\mathrm{AD}$ affects as much as $30-50 \%$ of the population of people over 85 years of age. Most often, within 3-9 years after the diagnosis of the disease, the patient dies (Isik 2010). Currently, $\mathrm{AD}$ represents a major challenge for modern science and medicine. Despite advanced research, AD aetiology has not been fully described yet, although it was proved that neurofibrillary tangles (NFT), excess of phosphorylated form of tau protein and senile plaques, which main component is the neurotoxic, abnormally folded $A \beta_{42}$ protein, play an important role in the initiation of the disease process and subsequent progression of the disease (Rozpedek et al. 2015, Armstrong 2009, Perl 2010).

Recent scientific reports suggest that in the case of many human diseases, including $\mathrm{AD}$, the initiation of the disease process begins at the molecular level. The accumulation of the neurotoxic form of $A \beta_{42}$ in the ER lumen leads to the initiation of conditions of ER stress and subsequent activation of the PERK-dependent UPR pathway (Heck et al. 2017). The aforementioned signal pathway plays a dual role: pro-adaptive, conditioning the maintenance of intracellular homeostasis in neurons of cerebral tissue, and pro-apoptotic (Huang et al. 2017, Rozpedek et al. 2015). The molecular mechanism of switching these opposing paths of the UPR pathway was not described in detail, but it is known that the pro-apoptotic pathway, leading to brain nerve cell death, is activated under conditions of increased and prolonged ER stress. Under conditions of ER stress, PERK, followed by its main substrate - eIF2 $\alpha$ protein, is phosphorylated. The translation of most proteins in the cell is inhibited in the next stage. However, a preferential increase in ATF4 proteins and $\beta$ secretase is observed, which determines the formation of the toxic form of $A \beta$ from APP (Hashimoto and Saido 2018, Jian et al. 2008). If it is not possible to restore homeostasis in the nerve cell at this stage, due to the intensification of ER stress conditions, the UPR pathway is switched to a pro-apoptotic pathway leading to a decrease in cerebral tissue mass observed in $\mathrm{AD}$. The main marker of apoptosis dependent on ER stress and PERK is the CHOP protein, which as a transcription factor regulates a number of pro- and anti-apoptotic genes. Overexpression of CHOP leads to inhibition of translation of anti-apoptotic proteins from Bcl-2 family and intensification of translation of pro-apoptotic proteins, such as Bax, Bak, Bok, Bok, Mim, Noxa, Puma. This molecular mechanism therefore determines the neurodegeneration process closely linked to $\mathrm{AD}$ progression 
(Li et al. 2015, Shore et al. 2011). In addition, CHOP is also a transcription factor for the gene encoding the EROla protein, the high level of which leads to neuron death as a result of intracellular ROS (Ferreiro et al. 2012, Yang et al. 2017)

There are numerous scientific confirmations that excessive activation of the PERK-dependent UPR pathway is closely correlated with the pathogenesis of $\mathrm{AD}$, which manifests in a significant decrease in the synthesis of neuronal proteins necessary to maintain proper learning and memory processes and the survival of nerve cells. Therefore, pharmacological inhibition of these processes may be an innovative neuroprotective strategy (Smith and Mallucci 2016). Numerous studies showed elevated levels of main markers of the UPR pathway, such as phosphorylated form of PERK and eIF2 $\alpha$ protein in the course of neurodegenerative diseases, including $\mathrm{AD}$ (Atkin et al. 2008, Hoozemans et al. 2007, Stutzbach et al. 2013). Inhibited translation of neuronal protein synthesis as well as elevated levels of phosphorylated form of PERK and eIF2 $\alpha$ were also demonstrated by studies carried out on human brains of patients diagnosed with $\mathrm{AD}$ (Chang et al. 2002, Chang et al. 2006). The main marker of activation of the UPR pathway of pro-apoptotic character is CHOP. It was proved that activation of $\mathrm{CHOP}$, in the course of $\mathrm{AD}$, leads directly to the generation of ROS in nerve cells, oxidative damage, intensification of amyloidogenesis, disturbances in the maintenance of iron homeostasis, activation of inflammatory processes, and as a result to the death of neuronal cells through apoptosis (Prasanthi et al. 2011). Studies conducted by Lee et al. showed excessive activation of PERK-dependent UPR pathway and significantly increased level of pro-apoptotic CHOP protein in SK-S-SH cells with APP overexpression, treated with $A \beta$ neurotoxic protein (Lee et al. 2010). Overexpression of $\mathrm{CHOP}$ correlated with apoptosis activation was also confirmed in the in vitro model on cell lines by Takahashi et al. (Takahashi et al. 2009). Overexpression of CHOP was also demonstrated in in vivo studies carried out on a mouse model of Alzheimer's disease. Studies conducted by Lee et al. suggest that CHOP overexpression in Tg2576 mice was correlated with excessive deposition of senile plaques in the cerebral tissue and cognitive function disorders (Lee et al. 2010).

Recent global studies suggest that the inhibition of the pro-apoptotic path of the PERK-dependent UPR pathway, leading to a decrease in intracellular ROS level, decrease in $\beta$ secretase activation and inhibition of accumulation of neurotoxic $A \beta$ deposits in the cerebral tissue, may be an innovative strategy in the treatment of $\mathrm{AD}$ (Prasanthi et al. 2011).

The inhibitor compounds of the pro-apoptotic pathway of PERK-dependent UPR, including GSK2606414, GSK2656157, Salubrinal and ISRIB, which have been tested so far, did not bring the expected effect because they were characterised by high cytotoxicity, non-selective action or poor solubility (Moreno et al. 2013, Moreno et al. 2012, Atkins et al. 2013, Halliday et al. 2017, Smith and Mallucci 2016).

The results of own research presented in this paper showed that the tested LDN-0060609 inhibitor at 25 $\mu \mathrm{M}$ concentration causes $80 \%$ decrease in the level of pro-apoptotic CHOP protein in mice CATH.a neurons with activated ER stress. In the cells of CATH.a. line with activated ER stress treated with LDN-0060609 inhibitor at the concentration of $25 \mu \mathrm{M}$, as many as $81.6 \%$ of live cells were found. Moreover, the tested inhibitor did not induce cytotoxic effect in any of the applied concentrations and incubation periods. Therefore, it can be concluded that the LDN-0060609 inhibitor exerts a significant effect on lowering the intracellular level of CHOP, and thus on inhibition of neuronal cell death by apoptosis. In conclusion, low-molecular inhibitors of pro-apoptotic PERK-dependent UPR pathway may be an innovative therapeutic strategy in the treatment of AD.

\section{Cel}

Choroba Alzheimera (Alzheimer's disease, AD) jest jedną z najczęstszych chorób neurodegeneracyjnych, której najbardziej znamiennymi cechami są spadek masy tkanki nerwowej mózgu oraz postępujące zaburzenia funkcji poznawczych (Hashimoto i Saido 2018, Kinney i wsp. 2018, Prasanthi i wsp. 2011). AD stanowi główną przyczynę demencji oraz przypadków otępienia u osób w podeszłym wieku. Obecnie szacuje się, iż liczba zachorowań na $\mathrm{AD}$ w 2050 roku na świecie może sięgnąć aż 130 milionów (Hashimoto i Saido 2018, Sun i wsp. 2018). Nieustająco wzrastający współczynnik zachorowalności

pociąga zatem za sobą konieczność dalszych badań nad etiologią oraz skuteczniejszymi terapiami w leczeniu $A D$ (Kinney i wsp. 2018). Patogeneza AD związana jest przede wszystkim z odkładaniem, głównie w hipokampie oraz korze mózgu, neurotoksycznych złogów amyloidu $\beta$ o długości 42 aminokwasów $\left(A \beta_{42}\right)$ (Salminen i wsp. 2009, Endres i Reinhardt 2013, Sun i wsp. 2018). Najnowsze doniesienia naukowe podkreślają, iż w rozwoju oraz progresji $\mathrm{AD}$ istotną rolę odgrywa aktywacja stresu retikulum endoplazmatycznego (Endoplasmic Reticulum, ER) w wyniku gromadzenia się nieprawidłowo sfałdowanych białek w lumen ER. Dochodzi wówczas do istotnych zaburzeń w sygnalizacji komórkowej, dysfunkcji 
w funkcjonowaniu neuronów, a następnie ich apoptozy, będącej kluczowym czynnikiem postępu choroby (Hashimoto i Saido 2018, Lindholm i wsp. 2006).

Istnieje wiele dowodów naukowych potwierdzających, iż zaburzenia szlaku adaptacyjnej odpowiedzi na stres (Unfolded Protein Response, UPR), w którym kluczową rolę odgrywa kinaza PERK (protein kinase RNA-like ER kinase), są ściśle związane z patogenezą i progresją licznych chorób człowieka, w tym tych o charakterze neurodegeneracyjnym (Wang i Kaufman 2012). Szlak UPR posiada dwojaką naturę, oprócz swojego proadaptacyjnego charakteru warunkującego zachowanie wewnątrzkomórkowej homeostazy, w warunkach nasilonego i przedłużającego się stresu ER może wykazywać charakter proapoptotyczny (Hashimoto i Saido 2018, Salminen i wsp. 2009). Dochodzi wówczas do autofosforylacji kinazy PERK, a następnie fosforylacji jej głównego substratu - czynnika inicjacji translacji 2 (eIF2) w podjednostce $\alpha$, co skutkuje zahamowaniem translacji większości białek w komórce (Endres i Reinhardt 2013). Wyjątek stanowią niektóre transkrypty posiadające sekwencje wiążące ufosforylowany czynnik eIF2, dzięki czemu dochodzi do zwiększenia poziomu translacji wyłącznie białek preferencyjnych, do których należy sekretaza $\beta$ (BACE1), enzym trawiący prekursorową formę A $\beta$ (amyloid precursor protein, APP). W rezultacie dochodzi do odłożenia większej ilości nieprawidłowej formy $\mathrm{A} \beta \mathrm{w}$ tkance mózgowej, a zatem pogłębienia stresu ER (Salminen i wsp. 2009). Jednocześnie pod wpływem ufosforylowanej formy czynnika eIF2 aktywacji ulega białko ATF4 (Activating Transcription Factor 4), stymulujące transkrypcję zarówno chaperonów, jak i białek indukujących proces autofagii i apoptozy (Hashimoto i Saido 2018, Endres i Reinhardt 2013). Do najważniejszych białek proapoptycznych związanych ze stresem ER należy CHOP (C/EBP homologous protein). W warunkach homeostatycznych ekspresja tego białka znajduje się na bardzo niskim poziomie, jednak pod wpływem proapoptotycznej ścieżki indukowanej przez kinazę PERK w warunkach stresu ER dochodzi do jej znacznego wzrostu (Nishitoh 2012). CHOP stanowi czynnik transkrypcyjny dla genów mogących decydować o przeżyciu lub śmierci komórki (Li i wsp. 2015). Jednym z kluczowych mechanizmów, dzięki któremu CHOP kontroluje wprowadzenie komórki na drogę apoptozy, jest hamowanie syntezy antyapoptotycznych białek z rodziny Bcl-2 (B-cell lymphoma 2) (Tabas i Ron 2011, Li i wsp. 2015). CHOP może również zwiększać poziom transkrypcji proapoptycznych członków rodziny Bcl-2, takich jak białko BAX, a także wpływać na ekspresję GADD34 (DNA damage-inducible protein), odpowiedzialnego za defosforylację eIF2, a co za tym idzie powodować przywrócenie wstrzymanej syntezy białek oraz nasilenie stresu ER (Rozpedek i wsp. 2016, Li i wsp. 2015). CHOP jest również odpowiedzialny za indukowanie stresu oksydacyjnego w świetle ER, poprzez włączanie transkrypcji endoplazmatycznej oksydazy $1 a$ (endoplasmic reticulum oxidase 1a, ERO1a), która promuje silnie utlenione środowisko wewnątrz ER oraz w cytoplazmie. Konsekwencją wzmożonej produkcji reaktywnych form tlenu (reactive oxygen species, ROS) wywołanej aktywacją proapoptotycznej drogi szlaku UPR zależnego od kinazy PERK może być apoptotyczna śmierć komórki oraz znaczący wzrost ekspresji sekretazy $\beta$, co dodatkowo potęguje oligomeryzację A $\beta$ (Tabas i Ron 2011, Prasanthi i wsp. 2011). Udowodniono, że zahamowanie ekspresji CHOP w istotny sposób wpływa na poziom białek rodziny Bcl-2, a także zmniejsza częstość występowania innych charakterystycznych dla $\mathrm{AD}$ procesów patologicznych, takich jak zwiększona produkcja $A \beta$, nasilenie stresu oksydacyjnego czy zaburzenia homeostazy żelaza, co wskazuje, iż obniżenie poziomu białka CHOP może mieć kluczowe znaczenie dla terapii AD (Prasanthi i wsp. 2011).

W związku z powyższym cele pracy stanowiły analiza niskocząsteczkowego związku LDN-0060609 pod względem jego aktywności inhibicyjnej proapoptotycznego szlaku UPR zależnego od kinazy PERK oraz ocena cytotoksyczności inhibitora LDN-0060609.

\section{Metoda}

Inhibitor LDN-0060609 został wyselekcjonowany we współpracy z laboratorium Profesora J. Alana Diehla (Medical University of South Carolina, Hollings Cancer Center, Charleston, USA) na podstawie dokowania komputerowego bazy niskocząsteczkowych związków zawartych w bibliotece Laboratory for Drug Discovery in Neurodegeneration (LDDN), testu TRF-FRET, radiometrycznego testu kinazowego, a następnie na podstawie analiz w modelu in vitro na liniach komórkowych.

Linia komórkowa neuronów mysich CATH.a (ATCC ${ }^{\circledR}$ CRL-11179 ${ }^{\mathrm{TM}}$ ), na której zostało przeprowadzone niniejsze badanie została pozyskana z Amerykańskiej Kolekcji Hodowli Komórkowych (American Type Culture Collection, ATCC; Manassas, VA, USA). Hodowla linii komórkowej CATH.a była prowadzona zgodnie z wytycznymi producenta na podłożu hodowlanym RPMI-1640 suplementowanym $8 \%$ surowicą końską (ATCC ${ }^{\circledR} 30-2040^{\mathrm{TM}}$ ), $4 \%$ płodową surowicą bydlęcą (ATCC 30-2020) oraz $100 \mathrm{U} / \mathrm{ml}$ penicyliną i 100 Mg/ml streptomycyną (Gibco-BRL, 15140-122). Hodowla komórkowa była prowadzona w temperaturze $37^{\circ} \mathrm{C}, 5 \% \mathrm{CO}_{2}$ oraz $95 \%$ wilgotności.

Komórki CATH.a zostały poddane godzinnej preinkubacji z testowanym inhibitorem LDN-0060609 w szeregu stężeń 6-50 $\mu \mathrm{M}$. Następnie komórki były traktowane tapsygarginą (Th), jako aktywatorem stresu ER, w stężeniu $500 \mathrm{nM}$ i poddane jednoczesnej inkubacji z Th oraz LDN-0060609 w czasie 2 godzin. Kontrolę pozytywną stanowiły komórki traktowane wyłącznie Th w stężeniu $500 \mathrm{nM}$ przez 2 godziny, natomiast kontrolę negatywną - komórki niepoddane działaniu żadnego związku. Dodatkową kontrolę stanowiły komórki poddane godzinnej preinkubacji z komercyjnie dostępnym inhibitorem 
GSK2606414 (GlaxoSmithKline) w stężeniu $1 \mu \mathrm{M}$, a następnie traktowane Th w stężeniu $500 \mathrm{nM}$ i poddane jednoczesnej inkubacji z Th oraz GSK2606414 w czasie 2 godzin.

Analiza poziomu białka CHOP została dokonana przy użyciu techniki Wester blot. Po uprzedniej inkubacji komórek linii CATH.a z testowanym związkiem LDN0060609 oraz Th zostały one zebrane i poddane lizie za pomocą buforu EBC (50 mM Tris- $\mathrm{HCl}, 120 \mathrm{mM} \mathrm{NaCl}$, $0.5 \%$ NP-40) z dodatkiem koktajlu inhibitora proteazy i fosfatazy (Thermo Fisher Scientific Inc., USA). Homogenat został zamrożony i był przechowywany w temperaturze $-80^{\circ} \mathrm{C}$ do momentu wykonania oznaczeń. Następnie $\mathrm{w}$ analizowanych próbach dokonano pomiaru ogólnej ilości białka za pomocą metody Bradforda. Krzywa kalibracyjna została wykonana przy użyciu szeregu rozcieńczeń surowiczej albuminy bydlęcej. Próby rozcieńczone buforem EBC oraz uzupełnione w stosunku 1:1 buforem denaturującym $2 \times$ Laemmli (Bio-Rad Laboratories, Hercules, CA) zawierającym 2-merkaptoetanol (Sigma-Aldrich Corp., St. Louis, MO, USA) zostały zdenaturowane w temperaturze $95^{\circ} \mathrm{C}$. Próby zawierające $90 \mu \mathrm{g}$ całkowitego białka poddano rozdziałowi elektroforetycznemu w $10 \%$ żelu poliakrylamidowym w warunkach denaturujących. Następnie białka zostały przeniesione z żelu na membranę PVDF (Immobion-P, Merck Milipore, Billerica, MA, USA) podczas elektrotransferu mokrego. Następnie membrana została poddana godzinnemu blokowaniu w temperaturze pokojowej w $5 \%$ roztworze odtłuszczonego mleka krowiego (Bio-Rad Laboratories, Hercules, CA) w buforze 1 X TBS/0,05\% Tween 20, aby zapobiec niespecyficznemu wiązaniu się białek na membranie. Membrany były inkubowane przez 16 godzin w temperaturze $4^{\circ} \mathrm{C}$ ze specyficznymi I-rzędowymi przeciwciałami: CHOP, $\beta$-aktyna $(1: 1000$; Cell Signaling Technology, Inc., Danvers, MA, USA). Następnie, po odpłukaniu nadmiaru przeciwciał I-rzędowych buforem 1 X TBST, membrany inkubowano przez godzinę $w$ temperaturze pokojowej z II-rzędowymi przeciwciałami skoniugowanymi z peroksydazą chrzanową (1:5000; Cell Signaling Technologies). Detekcja kompleksów immunologicznych została przeprowadzona przy użyciu zestawu chemiluminescencyjnego ECL (Bio-Rad Laboratories, Hercules, CA). Pomiar densytometryczny prążków wykonano przy użyciu oprogramowania Gene Tools (Syngene, Cambridge, UK). Ilość białka normalizowano względem sygnału otrzymanego dla $\beta$-aktyny jako białka referencyjnego.

Analiza apoptozy została wykonana za pomocą podwójnego barwienia aneksyną V (Ann-V) oraz jodkiem propidyny (PI) przy użyciu cytometrii przepływowej. Komórki, na $10 \mathrm{~cm}$ płytkach hodowlanych, zostały poddane godzinnej preinkubacji z inhibitorem LDN-0060609 w stężeniach $6 \mu \mathrm{M}$ i $25 \mu \mathrm{M}$, a następnie były traktowane Th w stężeniu $500 \mathrm{nM}$ i poddane jednoczesnej inkubacji z Th oraz LDN-0060609 w czasie 24 godzin. Komórki kontrolne były traktowane $10 \mathrm{ml}$ pożywki zawierającej
$1 \mu \mathrm{l}$ DMSO i inkubowane przez 24 godziny. Następnie komórki zostały zebrane, przepłukane w $1 \mathrm{X}$ buforowanej fosforanem soli fizjologicznej Dulbecco (DPBS, Corning, NY USA, 21-031). Komórki w stężeniu $1 \times 10^{6} / \mathrm{ml}$ zostały zawieszone w $1 \mathrm{X}$ buforze Binding Buffer, a następnie $100 \mu \mathrm{l}$ zawiesiny komórek $\left(1 \times 10^{5}\right.$ komórek) zostało przeniesionej do $5 \mathrm{ml}$ probówek typu Eppendorf. Każda $\mathrm{z}$ analizowanych prób była barwiona $5 \mu \mathrm{l}$ Ann-V oraz $5 \mu \mathrm{l}$ PI, zworteksowana i inkubowana w ciemności w temperaturze pokojowej przez 15 minut. Następnie każdą próbę rozcieńczono $400 \mu \mathrm{l} 1 \mathrm{X}$ buforu Binding Buffer i poddano analizie metodą cytometrii przepływowej przy użyciu cytometru Beckman Coulter CytoFLEX. Uzyskane dane były analizowane za pomocą oprogramowania Kaluza analysis 1.5A (Beckman Coulter).

Analiza cytotoksyczności badanego inhibitora LDN0060609 została wykonana za pomocą kolorymetrycznego testu XTT. Komórki linii CATH.a zostały zasiane na 96-dołkowej płytce hodowlanej w stężeniu $8 \times 10^{6} /$ dołek płytki hodowlanej zgodnie z zaleceniami producenta w odpowiedniej pożywce hodowlanej. Po 24 godzinach inkubacji pożywka została usunięta, a komórki były traktowane $100 \mu \mathrm{l}$ medium zawierającym badany inhibitor LDN-0060609 w stężeniach: $6 \mu \mathrm{M}, 12 \mu \mathrm{M}, 25$ $\mu \mathrm{M}, 50 \mu \mathrm{M}$ oraz 0,5 mM. Komórki traktowane $100 \mu \mathrm{l}$ pożywki hodowlanej zawierającej $1 \mu \mathrm{l}$ DMSO (Sigma-Aldrich Corp., St. Louis, MO, USA; 67-68-5), będącego rozpuszczalnikiem dla testowanego inhibitora, stanowity kontrolę pozytywną, natomiast komórki traktowane wyłącznie 100 ul 99.9\% DMSO kontrolę negatywną. Każda $\mathrm{z}$ analizowanych prób została wykonana w trzech powtórzeniach. Komórki inkubowano przez 16, 24 oraz 48 godzin. Odpowiednio po 16, 24, 48 godzinach do każdej próby dodano po $25 \mu \mathrm{l}$ mieszaniny XTT/PMS (Thermo Fisher Scientific Inc., USA; X-6493; AC130160010) przygotowanej zgodnie z zaleceniami producenta. Komórki inkubowano przez 2 godziny w temperaturze $37^{\circ} \mathrm{C}, 5 \%$ $\mathrm{CO}_{2}$ oraz $95 \%$ wilgotności. Absorbancja została zmierzona przy długości fali $450 \mathrm{~nm}$ za pomocą czytnika płytek Synergy HT (BioTek).

Analiza statystyczna została przeprowadzona za pomocą testu T-Studenta przy użyciu oprogramowania STATISTICA 10 (StatSoft).

\section{Wyniki}

Analiza poziomu proapoptotycznego białka CHOP w komórkach linii CATH.a wykazała jego najwyższy poziom w komórkach traktowanych wyłącznie Th jako aktywatorem stresu ER $\left(\mathrm{K}_{\mathrm{T}}\right)$. Po godzinie preinkubacji komórek z komercyjnie dostępnym inhibitorem GSK2606414 $(1 \mu \mathrm{M})$, a następnie 2 godzinach jednoczesnej inkubacji z GSK2606414 $(1 \mu \mathrm{M})$ oraz Th wykazano $79 \%$ spadek poziomu białka CHOP. W wyniku godzinnej preinkubacji komórek z testowanym inhibitorem LDN-0060609 
w stężeniu $25 \mu \mathrm{M}$ wykazano największy spadek (80\%) poziomu białka CHOP, w porównaniu z komórkami nietraktowanymi żadnym ze związków (K) (Rycina 1).
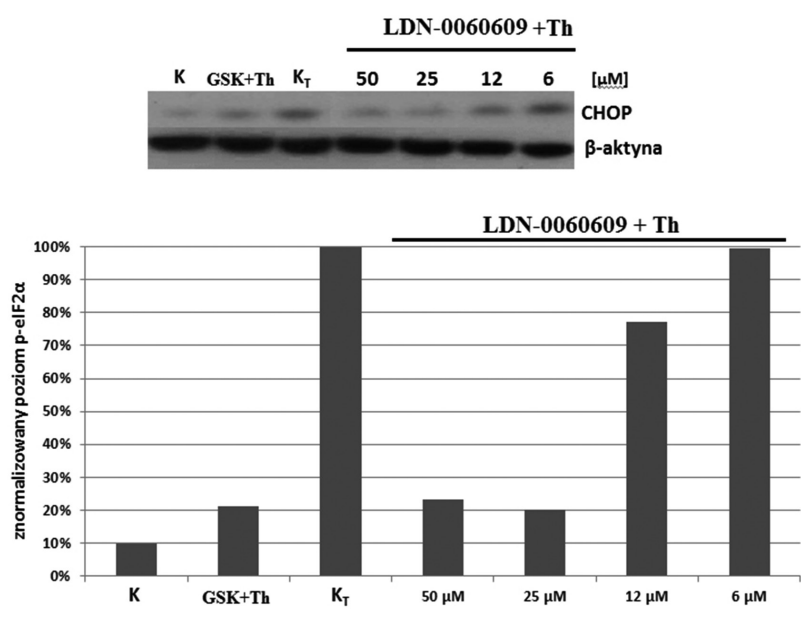

Rycina 1 Analiza właściwości inhibicyjnych związku LDN-0060609 przez ocenę poziomu proapoptotycznego białka CHOP w komórkach linii CATH.a. LDN-0060609 - testowany inhibitor; Th - tapsygargina; CHOP - białko C/EBP homologous protein; $\mathrm{K}$ - komórki nietraktowane; GSK+Th - komórki traktowane inhibitorem GSK2606414 oraz tapsygarginą; KT - komórki traktowane tapsygarginą

Analiza wpływu inhibitora LDN-0060609 na proces hamowania apoptozy w komórkach linii CATH.a. z aktywowanym stresem ER wykazała 81,6\% żywych komórek, 16,6\% - komórek we wczesnej i późnej apoptozie oraz $2 \%$ komórek w nekrozie w wyniku ich 24 -godzinnej inkubacji z testowanym inhibitorem LDN-0060609 w stężeniu $25 \mu$ M. 24-godzinna inkubacja komórek linii CATH.a, z aktywowanym stresem ER, z inhibitorem LDN0060609 w niższym stężeniu $(6 \mu \mathrm{M})$ wykazała $54,9 \%$ żywych komórek, 27,3\% - komórek we wczesnej i późnej apoptozie oraz 18,7\% - komórek w nekrozie. Zatem 24-godzinna inkubacja komórek CATH.a z aktywowanym stresem ER z inhibitorem LDN-0060609 w stężeniu $25 \mu \mathrm{M}$ wykazała jedynie o 5,6\% mniej żywych komórek w porównaniu z kontrolą, którą stanowiły komórki
CATH.a poddane 24-godzinnej inkubacji z 0,01\% DMSO będącym rozpuszczalnikiem dla testowanego inhibitora. W komórkach CATH.a z aktywowanym stresem ER traktowanych $25 \mu \mathrm{M}$ LDN-0060609 zaobserwowano jedynie o 5,1\% więcej komórek we wczesnej i późnej apoptozie w porównaniu z zastosowaną kontrolą (Rycina 2).

Analiza cytotoksyczności inhibitora LDN-0060609 wykonana za pomocą testu XTT nie wykazała jego istotnego wpływu na żywotność komórek linii CATH.a w żadnym z zastosowanych stężeń oraz czasów inkubacji. Nie uzyskano poziomu istotności statystycznej $(p<0,05)$ (Rycina 3).

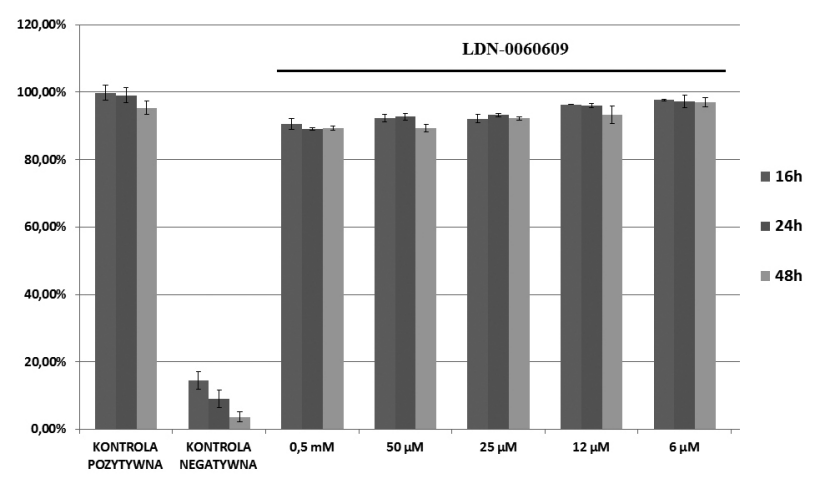

Rycina 3 Ocena cytotoksyczności inhibitora LDN-0060609 na komórkach linii CATH.a. LDN-0060609 - testowany inhibitor; kontrola pozytywna - komórki traktowane 0,01\% dimetylosulfotlenkiem; kontrola negatywana - komórki traktowane 99,9\% dimetylosulfotlenkiem

\section{Omówienie}

Choroba Alzheimera, należąca do grupy chorób neurodegeneracyjnych, charakteryzuje się występowaniem zaburzeń funkcji poznawczych, głównie pamięci, emocjonalnych oraz zachowania (Elferink i wsp. 2015). Jest ona najczęstszą przyczyną demencji, gdyż stanowi aż $75 \%$ wszystkich jej przypadków. Badania epidemiologiczne wskazują, iż ze względu na postępujący proces starzenia się społeczeństw zachorowalność na AD nieustannie
DMSO

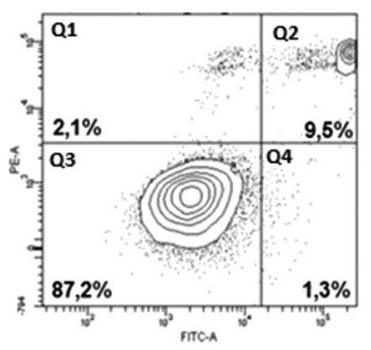

$6 \mu \mathrm{M}$ LDN-0060609+Th

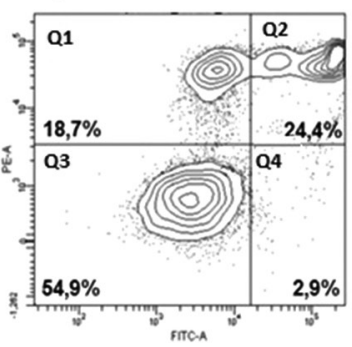

$25 \mu$ M LDN-0060609+Th

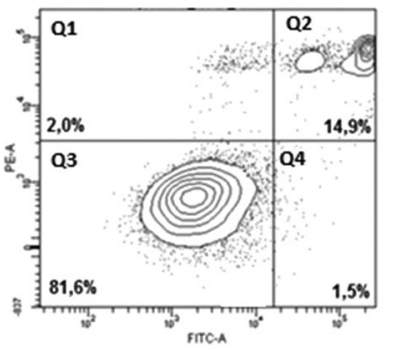

Rycina 2 Analiza wpływu inhibitora LDN-0060609 na proces hamowania apoptozy w komórkach linii CATH.a. DMSO - komórki traktowane 0,01\% dimetylosulfotlenkiem; LDN-0060609 - testowany inhibitor; Th - tapsygargina; Q1 - komórki nekrotyczne; Q2 - komórki późnoapoptotyczne; Q3 - komórki żywe; Q4 - komórki wczesnoapoptytyczne 
wzrasta, szczególnie u pacjentów pomiędzy 65. a 85. rokiem życia. Po 65. roku życia zachorowalność na AD podwaja się co 5 lat, dlatego obecnie AD dotyka aż 30-50\% populacji osób powyżej 85. roku życia. Najczęściej na przestrzeni 3-9 lat od momentu zdiagnozowania choroby dochodzi do śmierci pacjenta (Isik 2010). Obecnie AD stanowi ogromne wyzwanie dla współczesnej nauki i medycyny. Pomimo zaawansowanych badań etiologia $\mathrm{AD}$ nie została w pełni opisana, chociaż dowiedziono, iż w inicjacji procesu chorobowego oraz późniejszej progresji choroby istotną rolę odgrywają splątki neurofibrylarne (neurofibrillary tangles; NFT) będące nadmierną ufosforylowaną formą białka tau, oraz płytki starcze, których główny komponent stanowi neurotoksyczne, nieprawidłowo sfałdowane białko $\mathrm{A} \beta_{42}$ (Rozpedek i wsp. 2015, Armstrong 2009, Perl 2010).

Najnowsze doniesienia naukowe sugerują, iż w przypadku licznych chorób człowieka, w tym AD, inicjacja procesu chorobowego rozpoczyna się już na poziomie molekularnym. Akumulacja neurotoksycznej formy $A \beta_{42}$ w lumen ER prowadzi do zainicjowania warunków stresu ER, a następnie do aktywacji szlaku UPR zależnego od kinazy PERK (Heck i wsp. 2017). Wspomniany szlak sygnałowy posiada dualistyczną rolę: proadaptacyjną, warunkującą utrzymanie w neuronach tkanki mózgowej wewnątrzkomórkowego stanu homeostazy, oraz proapoptotyczną (Huang i wsp. 2017, Rozpedek i wsp. 2015). Molekularny mechanizm przełączenia tych przeciwstawnych sobie dróg szlaku UPR nie został dokładnie opisany, jednak wiadomo, iż droga proapoptotyczna, prowadząca do śmierci komórek nerwowych mózgu, aktywowana jest w warunkach nasilonego i długotrwałego stresu ER. W warunkach stresu ER dochodzi do fosforylacji kinazy PERK, a następnie jej głównego substratu białka eIF2a. Później natomiast zostaje zahamowana translacja większości białek w komórce. Obserwowany jest jednak preferencyjny wzrost białek ATF4 oraz sekretazy $\beta$ warunkującej powstanie toksycznej formy A $\beta$ z APP (Hashimoto i Saido 2018, Jian i wsp. 2008). Jeśli na tym etapie przywrócenie stanu homeostazy w komórce nerwowej jest niemożliwe, ze względu na nasilenie warunków stresu ER, szlak UPR zostaje przełączony na drogę proapoptotyczną prowadzącą do spadku masy tkanki mózgowej obserwowanej w AD. Główny marker apoptozy zależnej od stresu ER oraz kinazy PERK stanowi białko CHOP, które jako czynnik transkrypcyjny reguluje szereg genów zarówno pro- jak i i antyapoptotycznych. Nadekspresja CHOP prowadzi do zahamowania translacji białek antyapoptotycznych z rodziny Bcl-2 oraz nasilenia translacji białek proapoptotycznych, takich jak Bax, Bak, Bok, Mim, Noxa, Puma. Wspomniany mechanizm molekularny warunkuje zatem proces neurodegeneracji ściśle związany w progresją AD (Li i wsp. 2015, Shore i wsp. 2011). Ponadto, CHOP stanowi również czynnik transkrypcyjny genu kodującego białko EROla, którego wysoki poziom prowadzi do śmierci neuronów w wyniku wewnątrzkomórkowego ROS (Ferreiro i wsp. 2012, Yang i wsp. 2017).

Istnieją liczne potwierdzenia naukowe, iż nadmierna aktywacja szlaku UPR zależnego od kinazy PERK jest ściśle skorelowana z patogenezą AD, co przejawia się znacznym obniżeniem syntezy białek neuronalnych niezbędnych do utrzymania prawidłowych procesów uczenia się i pamięci oraz przeżycia komórek nerwowych. Farmakologiczna inhibicja wspomnianych procesów może zatem stanowić innowacyjną strategię neuroprotekcyjną (Smith i Mallucci 2016). Liczne badania wykazały podwyższony poziom głównych markerów szlaku UPR, takich jak ufosforylowana forma kinazy PERK oraz białka eIF2 $a$ w przebiegu chorób neurodegeneracyjnych, w tym AD (Atkin i wsp. 2008, Hoozemans i wsp. 2007, Stutzbach i wsp. 2013). Zarówno zahamowana translacja syntezy białek neuronalnych, jak i podwyższony poziom ufosforylowanej formy PERK oraz eIF2 $a$ wykazały także badania przeprowadzone na skrawkach ludzkich mózgów pochodzących od pacjentów cierpiących na $\mathrm{AD}$ (Chang i wsp. 2002, Chang i wsp. 2006). Główny marker aktywacji szlaku UPR o charakterze proapoptotycznym stanowi CHOP. Dowiedziono, iż aktywacja CHOP, w przebiegu AD, prowadzi bezpośrednio do generacji ROS w komórkach nerwowych, uszkodzeń oksydacyjnych, nasilenia procesu amyloidogenezy, zaburzeń w utrzymaniu homeostazy żelaza, aktywacji procesów zapalnych, a w rezultacie do śmierci komórek neuronalnych na drodze apoptozy (Prasanthi i wsp. 2011). Badania przeprowadzone przez Lee i wsp. wykazały nadmierną aktywacje szlaku UPR zależnego od kinazy PERK oraz znacząco podwyższony poziom proapoptotycznego białka CHOP w komórkach SK-S-SH, z nadekspresją APP, traktowanych neurotoksycznym białkiem A $\beta$ (Lee i wsp. 2010). Nadekspresja CHOP skorelowana z aktywacją procesu apoptozy została również potwierdzona w modelu in vitro na liniach komórkowych przez Takahashi i wsp. (2009). Nadekspresja CHOP została także wykazana w badaniach in vivo prowadzonych na mysim modelu choroby Alzheimera. Badania przeprowadzone przez Lee i wsp. sugerują, iż nadekspresja CHOP u myszy Tg2576 była skorelowana z nadmiernym odkładaniem blaszek starczych w tkance mózgowej oraz zaburzeniami funkcji poznawczych (Lee i wsp. 2010).

Najnowsze światowe badania sugerują, iż inhibicja proapoptotycznej drogi szlaku UPR zależnego od kinazy PERK, prowadząca do obniżenia wewnątrzkomórkowego poziomu ROS, spadku aktywacji sekretazy $\beta$ oraz zahamowania akumulacji neurotoksycznych złogów $A \beta$ w tkance mózgowej, może stanowić innowacyjną strategię w leczeniu AD (Prasanthi i wsp. 2011).

Dotychczas testowane związki inhibitorowe proapoptotycznej drogi szlaku UPR zależnego od kinazy PERK, do których należą GSK2606414, GSK2656157, Salubrinal oraz ISRIB, nie przynosiły spodziewanego efektu, gdyż 
charakteryzowały się wysoką cytotoksycznością, nieselektywnym działaniem lub słabą rozpuszczalnością (Moreno i wsp. 2012 i 2013, Atkins i wsp. 2013, Halliday i wsp. 2017, Smith i Mallucci 2016).

Wyniki badań własnych zaprezentowanych w niniejszym artykule wykazały, iż testowany inhibitor LDN0060609 w stężeniu $25 \mu \mathrm{M}$ wywołuje $80 \%$ obniżenie poziomu proapoptotycznego białka CHOP w mysich neuronach CATH.a z aktywowanym stresem ER. W komórkach linii CATH.a. z aktywowanym stresem ER traktowanych inhibitorem LDN-0060609 w stężeniu $25 \mu \mathrm{M}$ wykazano aż 81,6\% żywych komórek. Ponadto badany inhibitor nie wywołał efektu cytotoksycznego w żadnym z zastosowanych stężeń oraz czasów inkubacji. Można zatem stwierdzić, iż inhibitor LDN-0060609 ma istotny wpływ na obniżenie wewnątrzkomórkowego poziomu CHOP, a tym samym na hamowanie śmierci komórek neuronalnych na drodze apoptozy. Podsumowując, niskocząsteczkowe inhibitory proapoptotycznego szlaku UPR zależnego od kinazy PERK mogą stanowić nowatorską strategię terapeutyczną w leczeniu AD.

\section{Sources of funding / Źródła finansowania}

The work was supported by grants PRELUDIUM grant no. 2015/19/N/NZ3/00055 from the National Science Centre, OPUS no. 2016/21/B/NZ5/01411 from the National Science Centre, HARMONIA no. 2013/10/M/NZ1/00280 from the National Science Centre and by grant from the Medical University of Łódź no. 502-03/5-108-05/502-54-224-18. / Praca została sfinansowana $\mathrm{z}$ grantów PRELUDIUM nr 2015/19/N/NZ3/00055 przyznanego przez Narodowe Centrum Nauki, OPUS nr 2016/21/B/NZ5/01411 przyznanego przez Narodowe Centrum Nauki, HARMONIA $\mathrm{nr}$ 2013/10/M/NZ1/00280 przyznanego przez Narodowe Centrum Nauki oraz przez Uniwersytet Medyczny w Łodzi z zadania badawczego nr 502-03/5-108-05/502-54-224-18.
Conflict of interest was not declared. / Nie zgłoszono konfliktu interesów.

The work described in this article has been carried out in accordance with The Code of Ethics of the World Medical Association (Declaration of Helsinki) for experiments involving humans, EU Directive 2010/63/EU for animal experiments, and Uniform Requirements for manuscripts submitted to biomedical journals. / Treści przedstawione w artykule są zgodne z zasadami Deklaracji Helsińskiej, dyrektywami EU oraz ujednoliconymi wymaganiami dla czasopism biomedycznych.

Authors' contributions / Wkład autorów: WR - core contribution to the concept and design of the paper, statistical analysis and preparation of research results for analysis, collection of data and its interpretation, preparation of the bibliography / zasadniczy wkład w koncepcję i projekt pracy, analiza statystyczna i przygotowanie wyników badań do analizy, zebranie danych i ich interpretacja, zebranie piśmiennictwa; $J B$ - statistical analysis and preparation of research results for analysis, preparation of the bibliography / analiza statystyczna i przygotowanie wyników badań do analizy, zebranie piśmiennictwa; IS - statistical analysis and preparation of research results for analysis, preparation of the bibliography / analiza statystyczna i przygotowanie wyników badań do analizy, zebranie piśmiennictwa; RW - core contribution to the concept and design of the paper, preparation of the bibliography / zasadniczy wkład w koncepcję i projekt pracy, zebranie piśmiennictwa; DP - core contribution to the concept and design of the paper, preparation of research results for analysis, critical review of the significant intellectual content / zasadniczy wkład w koncepcję i projekt pracy, przygotowanie wyników badań do analizy, krytyczne zrecenzowanie pod kątem istotnej zawartości intelektualnej; JAD - core contribution to the concept and design of the paper, preparation of research results for analysis, critical review of the significant intellectual content, acceptance of the final version of the paper to be published / zasadniczy wkład w koncepcję i projekt pracy, przygotowanie wyników badań do analizy, krytyczne zrecenzowanie pod kątem istotnej zawartości intelektualnej, akceptacja ostatecznej wersji do opublikowania; IM - core contribution to the concept and design of the paper, critical review of the important intellectual content, acceptance of the final version of the paper to be published / zasadniczy wkład w koncepcję i projekt pracy, krytyczne zrecenzowanie pod kątem istotnej zawartości intelektualnej, akceptacja ostatecznej wersji do opublikowania.

\section{References / Piśmiennictwo}

1. Armstrong RA. The molecular biology of senile plaques and neurofibrillary tangles in Alzheimer's disease. Folia Neuropathol 2009; 47: 289-299.

2. Atkin JD, Farg MA, Walker AK, Mclean C, Tomas D, Horne MK. Endoplasmic reticulum stress and induction of the unfolded protein response in human sporadic amyotrophic lateral sclerosis. Neurobiol Dis 2008; 30: 400-407.

3. Atkins C, Liu Q, Minthorn E, Zhang SY, Figueroa DJ, Moss K et al. Characterization of a novel PERK kinase inhibitor with antitumor and antiangiogenic activity. Cancer Res 2013; 73: 1993-2002.

4. Chang RC, Wong AK, Ng HK, Hugon J. Phosphorylation of eukaryotic initiation factor-2alpha (eIF2alpha) is associated with neuronal degeneration in Alzheimer's disease. Neuroreport 2002; 13: 2429-2432.

5. Chang RC, Yu MS, Lai CS. Significance of molecular signaling for protein translation control in neurodegenerative diseases. Neurosignals 2006; 15: 249-258.

6. Elferink MW, Van Tilborg I, Kessels RP. Perception of emotions in mild cognitive impairment and Alzheimer's dementia: does intensity matter? Transl Neurosci 2015; 6: 139-149.

7. Endres K, Reinhardt S. ER-stress in Alzheimer's disease: turning the scale? Am J Neurodegener Dis 2013; 2: 247-265.

8. Ferreiro E, Baldeiras I, Ferreira IL, Costa RO, Rego AC, Pereira $\mathrm{CF}$ et al. Mitochondrial- and endoplasmic reticulum-associated oxidative stress in Alzheimer's disease: from pathogenesis to biomarkers. Int J Cell Biol 2012; 2012: 735206. 
9. Halliday M, Radford H, Zents KaM, Molloy C, Moreno JA, Verity NC et al. Repurposed drugs targeting eIF2\&alpha;-Pmediated translational repression prevent neurodegeneration in mice. Brain 2017; 140: 1768-1783.

10. Hashimoto S, Saido TC. Critical review: involvement of endoplasmic reticulum stress in the aetiology of Alzheimer's disease. Open Biol 2018; 8.

11. Heck GS, Pintro VO, Pereira RR, De Avila MB, Levin NMB, De Azevedo WF. Supervised Machine Learning Methods Applied to Predict Ligand- Binding Affinity. Curr Med Chem 2017; 24: 2459-2470.

12. Hoozemans JJ, Van Haastert ES, Eikelenboom P, De Vos RA, Rozemuller JM, Scheper W. Activation of the unfolded protein response in Parkinson's disease. Biochem Biophys Res Commun 2007; 354: 707-711.

13. Huang N, Yu Y, Qiao J. Dual role for the unfolded protein response in the ovary: adaption and apoptosis. Protein Cell 2017; 8: 14-24.

14. Isik AT. Late onset alzheimer's disease in older people. Clin Interv Aging 2010; 5: 307-311.

15. Jian B, Hsieh CH, Chen J, Choudhry M, Bland K, Chaudry I et al. Activation of endoplasmic reticulum stress response following trauma-hemorrhage. Biochim Biophys Acta 2008; 1782: 621-626.

16. Kinney JW, Bemiller SM, Murtishaw AS, Leisgang AM, Salazar AM, Lamb BT. Inflammation as a central mechanism in Alzheimer's disease. Alzheimers Dement (N Y) 2018; 4: 575-590.

17. Lee JH, Won SM, Suh J, Son SJ, Moon GJ, Park UJ et al. Induction of the unfolded protein response and cell death pathway in Alzheimer's disease, but not in aged Tg2576 mice. Exp Mol Med 2010; 42: 386-394.

18. Li Y, Guo Y, Tang J, Jiang J, Chen Z. New insights into the roles of CHOP-induced apoptosis in ER stress. Acta Biochim Biophys Sin (Shanghai) 2015; 47: 146-147.

19. Lindholm D, Wootz H, Korhonen L. ER stress and neurodegenerative diseases. Cell Death Differ 2006; 13: 385-392.

20. Moreno JA, Halliday M, Molloy C, Radford H, Verity N, Axten $\mathrm{JM}$ et al. Oral treatment targeting the unfolded protein response prevents neurodegeneration and clinical disease in prion-infected mice. Sci Transl Med 2013; 5: 206ra138.

21. Moreno JA, Radford H, Peretti D, Steinert JR, Verity N, Martin MG et al. Sustained translational repression by eIF2alpha-P mediates prion neurodegeneration. Nature 2012; 485: 507-511.

22. Nishitoh $\mathrm{H}$. CHOP is a multifunctional transcription factor in the ER stress response. J Biochem 2012; 151: 217-219.
23. Perl DP. Neuropathology of Alzheimer's disease. Mt Sinai J Med 2010; 77: 32-42.

24. Prasanthi JR, Larson T, Schommer J, Ghribi O. Silencing GADD153/CHOP gene expression protects against Alzheimer's disease-like pathology induced by 27-hydroxycholesterol in rabbit hippocampus. PLoS One 2011; 6: e26420.

25. Rozpedek W, Markiewicz L, Diehl JA, Pytel D, Majsterek I. Unfolded Protein Response and PERK Kinase as a New Therapeutic Target in the Pathogenesis of Alzheimer's Disease. Curr Med Chem 2015; 22: 3169-3184.

26. Rozpedek W, Pytel D, Mucha B, Leszczynska H, Diehl JA, Majsterek I. The Role of the PERK/eIF2alpha/ATF4/CHOP Signaling Pathway in Tumor Progression During Endoplasmic Reticulum Stress. Curr Mol Med 2016; 16: 533-544.

27. Salminen A, Kauppinen A, Suuronen T, Kaarniranta K, Ojala J. ER stress in Alzheimer's disease: a novel neuronal trigger for inflammation and Alzheimer's pathology. J Neuroinflammation 2009; 6: 41.

28. Shore GC, Papa FR, Oakes SA. Signaling cell death from the endoplasmic reticulum stress response. Curr Opin Cell Biol 2011; 23: 143-149.

29. Smith HL, Mallucci GR. The unfolded protein response: mechanisms and therapy of neurodegeneration. Brain 2016; 139: 2113-2121.

30. Stutzbach LD, Xie SX, Naj AC, Albin R, Gilman S, Group PSPGS et al. The unfolded protein response is activated in disease-affected brain regions in progressive supranuclear palsy and Alzheimer's disease. Acta Neuropathol Commun 2013; 1: 31.

31. Sun LL, Yang SL, Sun H, Li WD, Duan SR. Molecular differences in Alzheimer's disease between male and female patients determined by integrative network analysis. J Cell Mol Med 2018.

32. Tabas I, Ron D. Integrating the mechanisms of apoptosis induced by endoplasmic reticulum stress. Nat Cell Biol 2011; 13: 184-190.

33. Takahashi K, Niidome T, Akaike A, Kihara T, Sugimoto H. Amyloid precursor protein promotes endoplasmic reticulum stress-induced cell death via C/EBP homologous proteinmediated pathway. J Neurochem 2009; 109: 1324-1337.

34. Wang S, Kaufman RJ. The impact of the unfolded protein response on human disease. J Cell Biol 2012; 197: 857-867.

35. Yang Y, Liu L, Naik I, Braunstein Z, Zhong J, Ren B. Transcription Factor C/EBP Homologous Protein in Health and Diseases. Front Immunol 2017; 8: 1612. 